\title{
Značilnosti poezije osrednjih slovenskih pesnikov in pesnic, rojenih po letu $1970^{1}$
}

\author{
DAVID BEDRAČ \\ OŠ Ljudski vrt Ptuj, Župančičeva 10, SI - 2250 Ptuj, david.bedrac@guest.arnes.si
}

SCN VIII/2 [2015], 65-81

\begin{abstract}
$\mathrm{V}$ razpravo je zajetih enainšestdeset poetik slovenskih pesnikov in pesnic, rojenih po letu 1970. Predstavljene so nekatere prevladujoče značilnosti dane generacije na ravni zunanje in notranje oblike pesniških besedil, $v$ razpravo pa so zajeti ključni generacijski problemi pesništva, izhajajoči iz razmerja med avtopoetičnostjo in prevladujočimi idejnimi težnjami. Obenem je podan tudi krajši razmislek o najsodobnejših pesniških besedilih kot o razvojnem in idejnem kontinuumu znotraj slovenskega pesniškega prostora.
\end{abstract}

This paper discusses sixty-one forms of poetics utilized by Slovenian poets born after 1970. The discussion presents some dominant features of this generation at the level of external and internal forms of poetic texts and encompasses key generational problems of poetry which stem from the relationship between autopoetics and dominant ideational tendencies. At the same time it provides a shorter reflection of modern poetic texts viewed as a development and a conceptual continuum within Slovenian literary circles.

Ključne besede: slovenski pesniki, rojeni po letu 1970, avtopoetika, prevladujoči poetični vidiki, zunanja zgradba, notranja zgradba

Key words: Slovenian poets born after 1970, autopoetics, dominant poetic aspects, external structure, internal structure

${ }^{1} \mathrm{~V}$ razpravi, ki je nastala kot rezultat študij v okviru doktorske disertacije pri mentorici red. prof. dr. Silviji Borovnik, smo analizirali poetike naslednjih pesnikov in pesnic: Primoža Čučnika, Roberta Titana Feliksa, Stanke Hrastelj, Jurija Hudolina, Miklavža Komelja, Jaka Koširja, Mateja Krajnca, Petre Kolmančič, Gregorja Kosija, Tine Kozin, Gašperja Maleja, Klemna Piska, Gregorja Podlogarja, Barbare Pogačnik, Andraža Poliča, Marcella Potocca, Vida Sagadina, Jane Putrle Srdić, Lucije Stupica, Aleša Štegra, Alje Adam, Davida Bandlja, Davida Bedrača, Matjaža Brulca, Jasmine Cigrovski, Miljane Cunta, Tomaža Čeliga, Veronike Dintinjana, Anje Golob, Gala Gjurina, Jana Grabnarja, Andreja Hočevarja, Kristine Hočevar, Jureta Jakoba, Tatjane Jamnik, Tomislava Kiša, Kobrowskyjega, Jureta Novaka, Ane Pepelnik, Radharani Pernarčič, Katje Plut, Robija Simoniška, Jana Šmarčana, Tomislava Vrečarja, Gašperja Bivška, Sekumadyja Condeta, Karla Hmeljaka, Kristine Kočan, Simone Kopinšek, Tatjane Lapuh, Jelene Lasan, Sare Lubej, Marka Matičetovega, Tiborja Hrsa Pandurja, Eve Petrič, Marka Samca, Maje Visinski, Jureta Vuga, Lučke Zorko, Petre Zupančič in Barbare Žvirc. 


\section{Uvod}

Generaciji ${ }^{2}$ pesnikov in pesnic, rojenih po letu 1970 , literarni teoretiki, ${ }^{3}$ zgodovinarji in publicisti pripisujejo avtopoetičnost ter izrazni individualizem, med njihovimi poetikami pa naj bi po dosedanjih raziskavah stežka našli skupni idejni koncept oz. jih »spravi(li) pod hegemonijo velikega makropoetskega označevalca« (Kos 2004: 202). Pa vendar je po četrt stoletja trajajočem obdobju - njihovo objavljanje je vezano na leto 1990 in čas po njem - nujno, da ponovno pregledamo te poetike in opozorimo na nekatere prevladujoče poetične nastavke. Ker je pesniških glasov te generacije veliko, je nujno vzpostaviti raziskovalne kriterije, na podlagi katerih je določena poetika zajeta v raziskavo.

Ti so: a) število samostojnih knjižnih izdaj v obdobju 1990-2010 (najmanj ena pesniška zbirka, ki ne sme biti izdana v samozaložbi), b) najmanj dve objavi v slovenskih ali tujih literarnih revijah, ${ }^{4}$ c) kritiški odzivi (vsaj dva v kaki od slovenskih ali tujih literarnih revij), d) in morebitne prejete literarne nagrade.

\section{Nekatere prevladujoče poetične značilnosti ${ }^{5}$}

Čeprav je dana generacija poetično razdrobljena oz. »poetsko variabilna« (Novak Popov 2010: 180), lahko ugotavljamo veliko prevladujočih značilnosti in to na vseh ravneh pesniških besedil.

\subsection{Zunanja zgradba}

Pesmi lahko glede na naslove razdelimo v dve veliki skupini, in sicer na: a) nenaslovljene in b) naslovljene. Naslovi so največkrat sestavljeni iz ene do treh besed, daljše besedne zveze se pojavljajo redkeje, prehajajo pa lahko tudi $\mathrm{V}$ stavčno in povedno zasnovo. $Z$ vidika besednih vrst prevladujejo naslovi samostalniškega tipa: Vrba žalujka (Sagadin 2010: 28), Pesnik (Hudolin 2009: 34) oz. zveze s samostalniškim jedrom, okrog katerega se najpogosteje zbirajo pridevniki, npr. Fizični rob (K. Kočevar 2007), Zapuščeni kraji (Jakob 2010), Morski konjiček (Šteger 2005: 49). Raba drugih besednih vrst je redko zastopana.

\footnotetext{
${ }^{2}$ Gre za biološko določeno generacijo, ki pa jo povezujejo tudi mnoge skupne ideje.

${ }^{3}$ Strokovnjakov, ki bi se dani generaciji posvetili v širšem kontekstu, je zelo malo, prav tako primanjkuje resnih študij o njihovih poetikah - na individualni, še bolj pa generalni ravni. Prav zato je še bolj izpostavljena teorija avtopoetik.

${ }^{4}$ Pregledane so bile slovenske literarne revije, nekaj predstavnikov generacije pa smo zasledili tudi v nekaterih tujih revijah.

${ }^{5}$ Temeljni raziskovalni model je izhajal iz analize posameznih pesniških besedil, parcialne ugotovitve pa smo zatem strnili v prevladujoče značilnosti ene poetike, to pa smo nato primerjali s preostalimi, in tako prišli do nekaterih skupnih poetičnih značilnosti.
} 
Pojavljajo se tudi daljši naslovi, ki prehajajo v stavčno oz. celo povedno obliko, obenem pa so tudi vsebinsko kompleksnejši in praviloma že sodijo v tisti del poezije, ki stremi k inovativnosti in jezikovni revitalizaciji, npr. Ha-ha-ha-ha, to je pozaba (Čučnik 2005: 11-12), Zdavnaj obljubljena vmes večkrat uničena pesem (Komelj 2006: 31), Nasvidenje, grof Monte Christo (Krajnc 2008), Ki je žarel za svojo stojnico (Pernarčič 2008: 70). Sem sodijo tudi naslovi raznolikih obsegov, ki so v funkciji neposrednega priklica bralca, saj vsebujejo specifičen izrazni naboj, npr. PLANET A ali politična pesem, ki jo lahko mirno preskočite in bilo bi mi ljubše, da bi jo res preskočili (Condé 2003: 27-29), Deklaracija človeške odvisnosti (Hrs Pandur 2010: 65), Raz-stvaritev (Bivšek 2007: 31), Tudi meni gre (počasi) na smeh (Lasan 2009: 18).

Pri analizi kitic prav tako opazimo dve večji skupini, in sicer: a) kitično in b) nekitično zasnovane pesmi. Število kitic niha, a so po obsegu zelo dolge ${ }^{6}$ pesmi redke. Prav tako niha število verzov v posameznih kiticah, ki obsegajo od enega pa tudi do več kot deset verzov, in v nekitičnih pesmih, v katerih se lahko njihovo število giblje od enega samega pa do več deset. Na področju obsega verza (števila besed, ki posamezen verz gradijo) prav tako opazimo nihanje, vendar je največ verzov v območju srednjega obsega (med štiri do osem besed), zelo kratki (manj kot štiri besede) in zelo dolgi verzi (več kot osem besed) pa so zastopani redkeje.

Posebno skupino predstavljajo tista pesniška besedila, ki se zgledujejo po tradicionalnih pesniških modelih, med katerimi je še zlasti pomemben sonet. Ta se pri nekaterih od avtorjev pripeti kot »naključna« rešitev oz. ena od možnosti, ki jo pesništvo ponuja. Pojavljajo pa se tudi avtorji s celimi zbirkami sonetov, vendar je tudi pri njih sonet praviloma prisoten le $\mathrm{v}$ določenih ustvarjalnih obdobjih ali pa le-tega kombinirajo še z drugimi pesniškimi oblikami. Med osrednjimi pesniki, pri katerih opazimo sonete te vrste, so: Primož Čučnik, Matej Krajnc, Jaka Košir in Miklavž Komelj, čigar sonetistična zbirka Luč delfina (1991) sodi med pomembnejše tovrstne izdaje (Novak Popov 2003: 504).

Veliko inovativnosti najdemo na področju uporabe raznih likovnih učinkov. Ti so lahko lokalnega značaja, torej omejeni le na kakšen verz ali del le-tega, ali pa se razširijo na celotno pesem. Mestoma lahko v nekaterih primerih govorimo tudi o pravih likovnih pesmih.

Med najpogostejšimi likovnimi učinki opazimo: a) načrtne zamike verzov, npr. ... nevednost grobnica bo izzivalcev ... (Polič 2005: 47), b) različne črkovne fonte in tipe tiska, npr. $A N G E L$ (Kopinšek 2009: 13), c) simbole z različnih znanstvenih področij in znake, povezane s spletnim ter računalniškim okoljem, npr. slika kub isti čna. >: (Kobrowsky 2009: 111) ter d) prave likovne prvine (črte, puščice itd.), npr. čisto nori v naključju, čisti in 2006: 19), $\rightarrow$ (Plut 2001: 48), brez madežna (Adam 2008: 13).

\footnotetext{
${ }^{6}$ Pesmi z več kot desetimi kiticami v primeru kitičnosti oz. več kot petdesetimi verzi v primeru nekitičnosti.
} 


\subsection{Zunanji stil}

Področje zunanjega stila je med najzahtevnejšimi vprašanji, ki bi terjalo še več poglobljenih, ločenih študij (npr. posebno raziskavo metafore), a tudi na podlagi takega raziskovalnega modela opazimo nekaj prevladujočih značilnosti. Prav na področju zunanjega stila se kaže temeljna »ustvarjalna zadrega« te generacije, ki izhaja iz občutka tesnobe, saj je pesniški jezik skoraj docela izčrpan. To bi pesnike in pesnice sicer lahko vodilo v stanje ustvarjalne blokade, a prav upor zoper to jim daje temeljni zagon. Tako se poraja jezikovno-stilni vitalizem, ki ga določajo vsaj tri silnice: a) želja po revitaliziranem jeziku in zunanjem stilu, b) želja po odmikanju od starejših stilnih konceptov ali predelovanju le-teh $\mathrm{v}$ kontekstu parafraziranja in nekaterih intertekstualnih rešitev ter c) strah pred pretirano hermetičnostjo pesniških besedil.

Zunanji stil je tako izrazito dinamičen in nakazuje veliko izvirnih rešitev. Te pesniki in pesnice dosegajo z nadgradnjami stilnih prvin predhodnih generacij. Pojavljajo se stilna sredstva vseh vrst. Velika stopnja inovativnosti je prisotna zlasti na področju besednega stila, saj je opaziti veliko bogastvo poosebitev, npr. ... molk se je napihnil (Kočevar 2007: 13), Ni ladje, ki bi si upala odtrgati sidro (Jakob 2010: 58), metafor, metonimij, npr. PLANET Z VRTOM (Plut 2001: 19), Dežela pod Triglavom! (Vrečar 2004: 65), primer, npr. Tvoja duša je kot marmelada, / mehka in gnetljiva (Vuga 2009: 17), Po trebuhu sem kot kiti in jeziki sitih krav (Hmeljak 2007: 13), ki izgine kot bi ga pogoltnila zahrbtna avenija (Hrs Pandur 2010: 11), Zmeden kot vrabčkov let (Samec 2001: 39)) in sinestezij.

Pri analizi metafore opazimo izrazit poudarek na iskanju novih, posledično pa so te zato tako raznolike, npr. Veverice skačejo v prsi (Kočan 2008: 36), po hrupnem snegu (Lubej 2003: 132), o sij, uhajajoč iz mojih žil (Petrič 2007: 81), Kadar golobi, /.../ popuhajo zdrajsana lička devic (Zorko 2004: 31). V slovenskem pesništvu že uporabljene metafore nadgrajujejo, pogosto pa gre za popolnoma nove različice le-teh. Čeprav je metaforika območje številnih inovacij, pa ta le redko zaide $\mathrm{v}$ prostor hermetičnega in le $\mathrm{v}$ redkih primerih so zvočni učinki povsem pred pomenskimi.

Med pogostejšimi stilnimi sredstvi iz te skupine so tudi sinestezije, s katerimi želijo pesniki vplivati na bralca, ki pripada družbi intenzivnih in raznolikih dražljajev. ${ }^{7}$ V nekaterih pesmih se sinestezije združujejo v sheme, zaradi katerih pesmi dražljajsko učinkujejo na več ravneh, npr. šumi čigumijev (Zupančič 2010: 7), z galebovim krikom v srcu (Žvirc 2004: 45), močnati zrak iz mleka in semena (Titan Felix 2001: 15), snop / podhlajenih sončnih žarkov na kristale (Hrastelj 2005: 30).

Med akumulacijskimi in ogovornimi figurami se pojavljajo številna izvirna kopičenja, brez- in mnogovezja, npr. novo genezo, novo smrt, izvir nenehnega kroženja (Pisk 1998: 24), ker nisi dala jantarja, ker nimaš jantarja, ker nisi

\footnotetext{
${ }^{7}$ Pojav sinestezij je v tem oziru skladen z nekateri mehanizmi, po katerih deluje spletno in računalniško okolje. Ta problematika bi zahtevala ločeno študijo.
} 
dala zgodovine, / ker nimaš zgodovine (Čučnik 2002: 12), In prah. In pesek. In nekdanja hiša (Komelj 2008: 35). Pomembno vlogo pa lahko pripišemo še vzklikom in retoričnim vprašanjem, npr. pesnik sit! (Potocco 2002: 54), Kako preživeti morje, ki se ti izlije? (Pogačnik 2007: 54). Med prevladujočimi stilnimi sredstvi so tudi številna ponavljanja. Pri teh avtorji ponovno izčrpavajo stilne rešitve prejšnjih generacij, a jih tudi nadgrajujejo. Tako se pojavljajo razne anafore, epifore, geminacije, paralelizmi členov in refreni ${ }^{8}$ - vendar pa ponavljanja niso vedno rezultat načrtovanja, pač pa se v pesmih včasih zgolj »pripetijo《.

Poseben problem na področju zunanjega stila predstavlja rima, ki jo dana generacija zavestno zavrača. ${ }^{9}$ Pojavlja se le v treh primerih, in sicer: a) v zgodnejših pesmih nekaterih avtorjev in avtoric (npr. Samec, Hudolin, Šteger), b) v sonetih in štirivrstičnicah (npr. Krajnc, Komelj, Polič, Košir, Felix) ali c) kot povsem naključni pojav (npr. Kozin, Bedrač).

Nekateri pesniki so v začetnem razvojnem stadiju ustvarjanja, ko so svoj izraz šele oblikovali, posegali tudi po rimi, a jim ta ni omogočala dovolj novih izraznih možnosti, zato so se od nje umaknili. Kljub temu pa lahko ugotavljamo, da so, ko so jo uporabljali, pri tem iskali nove rešitve ali pa so že znane rime izvirno nadgradili. Tako nadgradnjo zasledimo tudi v sonetih, npr. ... pero / ... plese / ... samo / ... trese (Komelj 1991: 46).

Večkrat pa se rima v pesmih zgodi povsem naključno. Gre za vstavljanje, praviloma notranje rime, $v$ okolje, ki rimi sicer ni naklonjeno, zato ta učinkuje kot stilni »fosil«, npr. zastrta / priprta (Kozin 2010: 42).

Na področju logičnih figur prav tako opazimo inovativna sredstva vseh vrst, še najbolj pa pridejo do izraza nekatera izvirna pretiravanja in stopnjevanja, npr. Prekrij pokrajino, pogrni mizo, spravi / ljudi v postelje (Čučnik 1999: 61), greh iz mesa / greh iz jezika kakšne odprtine v životu (Kosi 2007: 60), Ulično utripanje. / Otroci na cesti. / Jure Detela (Podlogar 2006: 43).

\subsection{Zunanji ritem}

Zunanji ritem je zastavljen na tri načine, in sicer kot: a) ritem, temelječ na »klasični« metriki, b) ritem, značilen za pesem v prozi, in c) ritem, značilen za prosti verz.

Ritem v pesmih, ki temeljijo na klasičnih pesniških oblikah - v tem oziru še zlasti izstopa sonet - poteka po določeni metriki, ki pa ni nujno klasično stroga. Tako zasledimo pojav nekaterih jambskih zaporedij, ki pa se mestoma tudi prekinejo. Praviloma lahko v sonetu zasledujemo stalno število zlogov,

\footnotetext{
${ }^{8}$ Nekateri od avtorjev poezijo združujejo tudi z glasbo, npr. Gjurin, Krajnc in Polič. Na ta problem je opozorila tudi Irena Novak Popov v razpravi Pesnik in glasbenik: skica sodobnih stičišč.

${ }^{9}$ Nanašajoč se na značilnosti danih poetik in številne izjave pesnikov ter pesnic na literarnih večerih ali v sklopu različnih intervjujev.
} 
zaporedje poudarjenih in nepoudarjenih zlogov pa je le redkih pesmih povsem dosledno.

Ritem pesmi v prozi je zasnovan po načelih, značilnih za tak tip besedil. Menjavanje poudarjenih in nepoudarjenih zlogov je praviloma skladnejše s pripovednim tokom in tudi z notranjim ritmom posameznega pesniškega besedila.

Največkrat pa je zastopan prosti verz in temu primerna je tudi ritmična zasnova pesmi. Zaporedja poudarjenih in nepoudarjenih zlogov si sledijo po načelih »naravnega« poteka, vendar natančna analiza pokaže tudi, da na nekaterih mestih v pesmih prihaja do izrazitejšega kopičenja poudarjenih zlogov, spet na drugih so zaporedja nepoudarjenih zlogov pogostejša. Taka kopičenja prinašajo posebne zvočne učinke.

\section{Notranja oblika}

\subsection{Notranja zgradba}

V kontekstu notranje zgradbe je med osrednjimi gotovo vprašanje lirskega subjekta, za katerega je značilno, da se uresničuje na različne načine, a sta med njimi dva prevladujoča.

\subsubsection{Lirski subjekt}

Lirski subjekt je velikokrat avtorski, kar dokazujejo navedbe preverljivih krajev, literarnih prireditev in oseb, povezanih s pesniki in pesnicami, najpogosteje pa je fiktivni. Pojavlja se tako v ženski kot moški obliki, pri tem pa se najpogosteje uresničuje skozi prvo- ali drugoosebno perspektivo. Slednja mu omogoča nagovarjanje sebe kot »drugega«, oddaljenega jaza (Novak Popov 2010: 180), npr. Iz tvojega telesa raste okoli / tvojih kosti se ovija napenja // skozi tvojo medenico ... (Sagadin 2010: 46).

Tako oddaljevanje od lastne osebnosti pa pogosto prehaja $\mathrm{v}$ brezosebno obliko, ko se lirski subjekt iz pesmi s svojo psihofizično substanco skoraj povsem umakne. To lahko izpelje s povečano mero fokusiranja na določene predmete ali z opisi stvarnega sveta in prostorov, lahko pa tudi z opazovanjem drugih subjektov - vendar z izrazito distanciranostjo., npr.: s svojega telesa / slačim tematske sklope (Čelig 2007: 27).

$\mathrm{V}$ nekaterih od poetik subjekt izpoveduje široka »spoznanja« o (so)ljudeh ali prehaja celo iz enega $\mathrm{v}$ drug čas, pri tem pa našteto praviloma opazuje $\mathrm{s}$ kozmične perspektive, zato lahko v takih primerih govorimo tudi o nadsubjektu, npr.: Med tankim nebom / in globokim odsevom / mirujeta dve črti: // ena loči nebo od vode, / druga izčrpani jezik od teže dotikov (Potocco 2002: 44). 


\section{Osrednje teme}

Analiza tem na eni strani pokaže veliko raznolikost med posameznimi avtorji, na drugi strani pa opazimo tematska področja, ki močno prevladujejo.

\section{a) Tema pesništva in pesnika}

Pesnik je predstavljen kot vsakdanji človek. Pesništvo je demitizirano, le redko je čaščeno v smislu enigmatičnega, visoko estetskega procesa, neposredno povezanega z inspirativnimi silnicami, npr. v odlomku pesmi Nič takega pesem Anje Golob:

Vendar, pesmi pridejo.

Ko lulaš, ješ, berě̌ druge pesmi,

ko se učiš, plavaš, po orgazmih,

na predavanjih, ko šofiraš, ko presajaš rože.

Pridejo zaporedja besed, ki dovolj dobro zvenijo. (Golob 2010: 12)

Pesnjenje je tako eden od načinov komunikacije s svetom, zato večkrat postane povsem vsakdanje opravilo: vem da moram / obesiti perilo že od včeraj I stoji nenapisana pesem (Adam 2008: 45).

Nekatere od poetik gledajo na pesništvo celo kot na neestetsko in neučinkovito jezikovno paradigmo, nekakšen "pljunek" v svet, ki se dotakne le redkih ušes, spet druge gledajo nanj kot na veliko laž, nepotrebno estetsko iluzijo, npr. v pesmi Marka Samca Črke:

Črke zamišljeno bivajo.

Črke so zajedavci.

Črke olajšano rignejo,

Ko se jim zazdi,

Da so napizdile dovolj ljudi. (Samec 2004: 33)

\section{b) Tema intelektualca}

Intelektualec je predstavljen kot eksistencialno obremenjen posameznik z izrazitimi notranjimi konflikti. Če mu znanje predstavlja duhovno širino na eni strani, mu po drugi prinaša obremenitev, saj v družbi načeloma nima ustrezne pozicije in življenja dostojnega socialnega položaja. ${ }^{10}$ Ta tema se tako razvija na mnoge načine, pri tem pa prehaja od realističnih, preko komičnih in ironičnih dimenzij, vse do grotesknih, npr.

${ }^{10} \mathrm{O}$ tej problematiki so na okrogli mizi z naslovom Generacija razpravljali Blaž Kosovel, Jaša Lorenčič, Izak Lunaček, Katja Perat, Uroš Prah, Anja Radaljac, Manca Renko, Andrej Tomažin, Urban Zorko. Na to temo je tudi članek Andreja Hočevarja Generacija po izbiri. 
Priznaj, da si beden, ko šiliš pero in bolščeč v sončni žarek / upaš, da bo pisala verze iz lastnega veselja do tvoje besede (Šmarčan 2007: 52).

c) Tema jezika

Jezik, ki je temeljno orodje pesniškega ustvarjanja, se razpira skozi paradoks. Ker so ga pretekle pesniške struje že dodobra »iztrošile«, je neizbežno »prenikanje v neizrekljivo in prepoznavanje omejitev jezika« (Novak Popov 2010: 180); zato terja, posledično, doseganje učinkovitega, neklišejskega, »novega« jezika izrazit napor. Obenem pa prav to predstavlja enega od osrednjih ustvarjalnih načel, npr. v nenaslovljeni pesmi Aleša Štegra:

Iz sebe vzameř.

Nesě̌, ne dojameř.

Daš v nič.

Preden zraste novo.

Vzameš nemo možnost.

Spet nosiš.

Praznina s kravato.

Vozel besed.

Gre skozi svet.

Iz sebe $v$ nič.

Potem še sebe $v$ nič.

Daš. Te odloži.

Res čuden svet.

Beseda odpre oči,

Kjer ni besed. (Šteger 2010: 27)

d) Tema posameznika v dvojini in kolektivu

To tematsko področje zajema več ožjih podsklopov, med katerimi izstopajo trije, in sicer: a) posameznik kot bitje ustvarjalne izolacije in samote, b) posameznik kot družbeno angažiran in kritičen opazovalec kolektiva, c) posameznik kot bitje med ednino in ljubezensko-erotično dvojino.

Pesnjenje zahteva odmik od okolice, senzorno umiritev, slednje pa je mogoče le, kadar je subjekt mentalno in fizično izoliran od drugih. Običajno s take pozicije tudi opazuje družbo, pri tem pa odpira mnoga družbeno pereča vprašanja, s čimer se nekatere od poetik premikajo tudi v območje angažirane lirike, saj »(p)esniki postajajo analitiki globalnih in lokalnih družbenih anomalij: materializma, potrošništva, kapitalskega izrabljanja človeških in naravnih virov, trgovine, prevlade videza, uspešnosti, odkritega in prikritega nasilja« (Novak Popov 2010: 181). Slednje zasledimo v odlomku iz pesmi Nakupovalci Davida Bedrača: 
Brskaš po policah. In polniš vozičke.

In jih odrivaš proč, a se vrnejo.

Pokličejo te. In ti pritečeš in kupuješ.

l...l

In te prodajalka lepo pogleda,

in ker se med nakupom s svojim vozičkom

nisi v nikogar zaletel,

dobiš še srebrno nalepko za brezplačno parkiranje

prihodnjič. (Bedrač 2010: 6)

Pogosta tema je tudi intimni odnos z drugim človekom, največkrat nasprotnega spola, čeprav se pojavljajo tudi druge spolne prakse, npr. bi- in homoseksualnost pa tudi razne oblike fetišizma in sadizma. Odnos med subjektom in drugim je lahko umirjen, harmoničen, še pogosteje pa je turbulenten, ${ }^{11}$ poln vprašanj in dvomov. Tesno $v$ zvezi z ljubezensko in erotično tematiko je tudi izražanje z besedami, ki označujejo različne dele telesa in organe (npr. usta, glava, jezik, oči, prsti, srce), s čimer se odnos med dvema še stopnjuje, mentalno pa preide na telesno raven, npr. v odlomku pesmi Slečena Andraža Poliča:

Gol stojim pred tabo.

Počasi si slekla z mene vse besede.

Nimam več svoje kože, da bi se oblekel.

Molčiva.

In se gledava.

A jaz nimam več oči, da bi videl.

Nimam več niti glave, da bi mislil.

Niti srca, da bi čutil. (Polič 2010: 83)

e) Tema relativnosti in parcialnosti lastne resnice

Lirski subjekt se zaveda, da so njegove zaznave omejene, prav tako je njegovo doživljanje sveta le delček univerzalnega. Iz občutka, da je vse relativno (Straši me, kar pravi Bohr, / Da sem relativen tudi jaz (Šteger 2002: 73)) in da je izpoved njegove resnice mikrodelec celotnega univerzuma, se poraja tematsko področje »majhnosti« subjekta, večkrat pa tudi malovrednosti in zavedanja »nerelevantnosti«, omejenosti izrekanja misli in idej v odnosu do kolektiva, kot je to razvidno v odlomku pesmi Jesenski večer Lučke Zorko:

Edina luna ki jo lahko dosežem

je ta ki odseva $v$ meni.

Na ta tihi neznatni

jesenski večer. (Zorko 2006: 49)

${ }^{11}$ Niso redki primeri ekstremnih afektivnih stanj pa tudi nekaterih širših deviantnih vzgibov. 


\section{Idejne usmeritve}

Dana generacija še vedno ustvarja na ozadju postmodernizma, vendar se od tega tudi vse bolj odmika. S postmodernizmom jo povezuje med drugim pojav tudi zanj značilne intertekstualnosti, saj si avtorji »očarani z medliterarnimi navezavami med predhodniki ali generacijskimi tovariši izbirajo naslovnike svojih dialoško naravnanih besedil« (Novak Popov 1999/2000: 115). Na povezanost s postmodernizmom pa pokažejo še mnogi drugi postopki, predvsem sta $\mathrm{z}$ njim v povezavi logika relativizma in občutek malovrednosti izpovedovanja »resnice« pesniškega individuuma.

Po drugi strani se nakazujejo mnogi elementi, kakršne je gojil modernizem, še zlasti ko gre za vprašanje preizkušanja jezikovnih meja, dekonstruiranja »starega« in rekonstruiranja »novega« jezika ter nekaterih drznih stilnih prijemov, vendar se modernistični elementi običajno mešajo s številnimi drugimi. Med takimi, ahistoričnimi, so na primer elementi novega intimizma (Košuta 2009: 19-20), pojavljajo pa se še prvine eksistencializma, impresionizma, ekspresionizma, nadrealizma, romantike in nove romantike ter v nekoliko manjši zastopanosti še mnoge druge.

\section{Sklep}

Poezijo pesnikov in pesnic, rojenih po letu 1970, zaznamujejo nekateri prevladujoči poetični nastavki. Na ravni zunanje zgradbe smo tako praviloma priča kratkim, izrazno šibkim naslovom, prav tako ni zaznati velikih posebnosti na ravni obsega pesmi. Se pa pogosto pojavljajo mnogi likovni učinki in elementi, povezani s sodobnimi tehnologijami in spletom. Zunanji stil, ki je posledica mnogih ustvarjalnih konfliktov s preteklimi obdobji, smermi in gibanji, teži k ravnovesju med izpovedano vsebino in jezikovnimi inovacijami; stilna sredstva se pojavljajo v raznolikih oblikah, nekatere pa generacija razume kot preživete in za današnji čas neučinkovite (npr. rimo). Velike sorodnosti so tudi na ravni notranje oblike, še zlasti notranje zgradbe, saj opazimo prisotnost nekaterih prevladujočih tem, med katerimi izstopajo: pesnik/pesnica, pesnjenje in položaj le-tega v sodobni družbi, spoznanje o parcialnosti lastne izpovedi in večkrat prisoten konflikt med jezikovnim vitalizmom na eni strani ter jezikovno tesnobo na drugi.

Seveda pa področje notranje zgradbe priča tudi o raznorodnosti poetik, ki se kaže zlasti v kontekstu lirskega subjekta. Tega ob sicer številnih prevladujočih zaznamuje še več izrazito individualnih značilnosti, razlike pa je zaznati tudi $\mathrm{v}$ obravnavi nekaterih specifičnih tem in motivov.

$\mathrm{Na}$ podlagi študij zunanje in notranje oblike pesniških besedil lahko tako ugotovimo, da je dana generacija notranje sicer še precej razdrobljena in da je teorija avtopoetik v tem kontekstu upravičena. Po drugi strani pa lahko ugotavljamo, da obstaja veliko vse bolj prevladujočih, celo skupnih idejnih nastavkov 
in ustvarjalnih teženj, zato je nujno opazovati nadaljnji razvoj poetik dane pesniške generacije, ki tako postopoma vse bolj presega zgolj oznako biološka.

\section{VIRI IN LITERATURA}

Alja ADAM, 2003: Zaobljenost. Ljubljana: Center za slovensko književnost.

- -, 2008: Zakaj bi omenjala Ahila. Ljubljana: Center za slovensko književnost.

David BANDELJ, 2000: Klic iz nadzemlja. Trst: Mladika.

David BEDRAČ, 1998: Neskončnost. Ptuj.

--, 2002: Poezija pomolov. Maribor: Litera.

- -, 2002: Razvoj poezije Jurija Hudolina na ozadju postmodernizma. Maribor: Pedagoška fakulteta Maribor.

- -, 2004: Rad sem hodil tja gor in mislil na robu obrobne misli: poskus označitve najmlajše pesniške generacije na Slovenskem. Mentor, 25/5, 51-59.

- -, 2006: Pesmi iz šipe. Ptuj: UD Stara steklarska.

--, 2006: Razprti svetovi, 2006. Trst: Mladika.

- -, 2007: Brez uteži. Ljubljana: JSKD; Mentor.

- -, 2007: Poezija kot igra energij. Mentor 28/1-2, 66-67.

- -, 2010: Centimetri sveta. Maribor: Litera.

- -, 2011: Poezija v ostenjih današnjega časa. Mentor 32/4, 55-66.

Tina BILBAN, 2008: Problem časa v sodobni slovenski poeziji. Primerjalna književnost 31/2, 67-91.

Gašper BIVŠEK, 2007: Skorjevec. Ljubljana: Založba Beletrina.

Matjaž BRULC, 2006: Balade za psa in prhljaj. Ljubljana: KUD France Prešeren.

Jelka CIGLENEČKI, 2010: Zbornik Dnevov poezije in vina. Ljubljana: Študentska založba.

Jasmina CIGROVSKI, 2001: V popku. Maribor: Litera.

Sekumady CONDÉ, 2000: Kaligandanga. Maribor: Mariborska literarna družba.

- -, 2003: Maratajana. Maribor: Locutio, zavod za kulturno iniciativo.

Jonathan CULLER, 2008: Literarna teorija (Zelo kratek uvod). Ljubljana: Krtina.

Miljana CUNTA, 2010: Za pol neba. Ljubljana: Založba Beletrina.

Tomaž ČELIG, 2004: Lutke. Maribor: Litera.

- -, 2007: Fetiš. Maribor: Subkulturni azil.

Primož ČUČNIK, 1999: Dve zimi. Ljubljana: Aleph. 
- -, 2002: Ritem v rôkah. Ljubljana: Center za slovensko književnost.

--, 2003: Oda na manhatanski aveniji. Ljubljana: LUD Šerpa.

--, 2004: Akordi. Ljubljana: LUD Šerpa.

- -, 2005: Nova okna. Ljubljana: LUD Literatura.

- -, 2006: Sekira v medu. Ljubljana: LUD Šerpa.

- -, 2007: Delo in dom. Ljubljana: LUD Literatura.

- -, 2010: Kot dar. Ljubljana: LUD Šerpa.

Veronika DINTINJANA, 2008: Rumeno gori grm forzicij. Ljubljana: LUD Literatura.

Dubravka ĐURIĆ, 2011: Slovenska poezija, prešernovska struktura in politika pesniške forme. Primerjalna književnost 34/1, 35-48.

Robert Titan FELIKS, 1993: Pesem o dotiku. Murska Sobota: Septima.

- -, 1994: Magnifikat. Murska Sobota: Pomurska založba.

- -, 1997: Benedictus: psalmi. Murska Sobota: Pomurska založba.

- -, 2001: Knjiga o razbitem času. Grosuplje: Mondena.

--, 2003: Pekel spomladi. Murska Sobota: ZKD.

Gal GJURIN, 2002: Mesto. Grosuplje, Mondena.

Anja GOLOB, 2010: V roki. Maribor: Litera.

Jan GRABNAR, 2002: Orkin spev. Ljubljana: Škuc.

Karlo HMELJAK, 2007: Dve leti pod ničlo. Ljubljana: LUD Literatura.

Andrej HOČEVAR, 2002: Vračanja. Ljubljana: Center za slovensko književnost.

--, 2005: Ribe in obzornice. Maribor: Litera.

--, 2007: Pesmi o koscih in podobnostih. Ljubljana: LUD Literatura.

- -, 2009: Privajanje na svetlobo. Ljubljana: LUD Literatura.

- -, 2014: Generacija po izbiri. Ljubljana: LUD Literatura.

Kristina HOČEVAR, 2004: V pliš. Ljubljana: Cankarjeva založba.

- -, 2007: Fizični rob. Ljubljana: Cankarjeva založba.

--, 2008: Repki. Ljubljana: Škuc.

- -, 2009: Nihaji. Ljubljana: Cankarjeva založba.

Stanka HRASTELJ, 2005: Nizki toni. Novo mesto: Goga.

- -, 2009: Gospod, nekaj imamo za vas. Ljubljana: Založba Beletrina.

Jurij HUDOLIN, 1991: Če je laž kralj. Zagorje: Kulturna skupnost Zagorje.

- -, 1992: Ajdbog in ptičvolkkača. Grosuplje: Mondena.

--, 1993: Bestije. Novo mesto: Dolenjska založba. 
- -, 1993: Divjanje. Ljubljana: Društvo slovenskih pisateljev.

- -, 1998: Prividi nemirnega čudaka. Ljubljana: Karantanija.

- -, 2001: Govori ženska. Ljubljana: Beletrina.

- -, 2009: Ljubezni. Ljubljana: Nova revija.

Jure JAKOB, 2006: Budnost. Ljubljana: LUD Literatura.

--, 2009: Tri postaje. Ljubljana: LUD Literatura.

- -, 2010: Zapuščeni kraji. Ljubljana: LUD Literatura.

Tatjana JAMNIK, 2009: Brez. Ljubljana: Center za slovensko književnost.

Marko JUVAN, 2006: Literarna veda v rekonstrukciji. Ljubljana: Literarno-umetniško društvo.

Tomislav KIŠ, 2008: Kremenov kamen s sonca. Maribor: Mariborska literarna družba. Matjaž KMECL, 1996: Mala literarna teorija. Ljubljana: Založba M\&N.

KOBROWSKY, 2009: Najprej semza slišal pr denje. Ljubljana: Cankarjeva založba.

Kristina KOČAN, 2008: Šara. Maribor: Litera.

Petra KOLMANČIČ, 1994: Luknja. Pesnica: Frontier ZKO.

- -, 1995: Šus v glavo. Pesnica: Frontier, ZKO Pesnica.

--, 1999: Slina. Pesnica: Frontier ZKD.

--, 2004: Uvod v poželenje. Maribor: Subkulturni azil, zavod za umetniško produkcijo in založništvo.

Peter KOLŠEK, 2006: Nevihta sladkih rož (Antologija slovenske poezije 20. stoletja). Ljubljana: Beletrina.

Miklavž KOMELJ, 1991: Luč delfina. Celovec, Salzburg: Wieser, cop.

- -, 1995: Jantar časa. Ljubljana: Živa.

--, 2002: Rosa. Ljubljana: MK.

- -, 2006: Hipodrom. Ljubljana, MK.

- -, 2007: Nenaslovljiva imena. Ljubljana: LUD Literatura.

- -, 2010: Nujnost poezije: eseji. Koper: Hyperion.

Simona KOPINŠEK, 2009: Antahkaran in drugi obrazi Lepote. Maribor: Pivec.

Janko KOS, 1993: Lirika. Ljubljana: DZS.

--, 1994: Očrt literarne teorije. Ljubljana: DZS.

Matevž KOS (ur.), 2004: Mi se vrnemo zvečer. Mlada slovenska poezija 1991-2003 (Zbirka Beletrina). Ljubljana: Študentska založba.

Gregor KOSI, 2007: Mik mik. Maribor: Subkulturni azil, zavod za umetniško produkcijo in založništvo.

Jaka KOŠIR, 1997: Draguljarna Rim. Ljubljana: Mladinska knjiga. 
- -, 2001: Smehljaj. Ljubljana: Mladinska knjiga.

- -, 2004: Nežnost. Ljubljana: Mladinska knjiga.

--, 2008: Srečanje z angelom. Celje: Celjska Mohorjeva družba.

Miran KOŠUTA (ur.), 2009: Decametron, dieci poeti sloveni contemporanei (Litterae Slovenicae). Ljubljana: Slovene Writers' Association.

Tina KOZIN, 2010: Mož s petimi podplati. Maribor: Litera.

Matej KRAJNC, 1997: Trenutki življenja. Celje: Zveza kulturnih organizacij.

- -, 1998: Razpoloženja. Celje: samozaložba.

- -, 2000: Medmavričje. Ljubljana: KUD Štempihar.

--, 2003: Vsakdanjost, soneti. Celje: KUD Štempihar.

- -, 2004: Tri pesnitve, soneti. Celje: KUD Štempihar.

- -, 2005: Preteklost. Celje: KUD Štempihar.

-, 2006: Groteske, soneti. Celje: KUD Štempihar.

- -, 2006: Orbisoneti. Celje: KUD Štempihar.

- -, 2007: Rohneča žetev. Ljubljana: Ved.

- -, 2007: Balade in arogance. Celje: KUD Štempihar.

--, 2008: Nasvidenje, grof Monte Christo. Ljubljana: Ved.

--, 2010: Iztočnice, soneti. Celje: samozaložba.

Tatjana LAPUH, 2001: Preludij v žitu. Ljubljana: JSKD, Mentor.

Jelena LASAN, 2009: Umómo. Ljubljana: Center za slovensko književnost.

Sara LUBEJ, 2003: Hladen pot. Ljubljana: ŠKUC.

Gašper MALEJ, 2004: Otok, slutnje, poljub. Ljubljana: ŠKUC.

- -, 2009: Rezi v zlatem. Ljubljana: Center za slovensko književnost.

Marko MATIČETOV, 2006: Vvsaki stvari je ženska. Ljubljana: KUD Franceta Prešerna. - -, 2009: Boš videl. Ljubljana: KUD Franceta Prešerna.

Boris A. NOVAK, 2005: Zven in pomen: študije o slovenskem pesniškem jeziku. Ljubljana: Filozofska fakulteta.

Jure NOVAK, 2001: 25. Ljubljana: Center za slovensko književnost.

Tibor Hrs PANDUR, 2010: Enerđimašina. Ljubljana, Center za slovensko književnost.

Darja PAVLIČ, 2003: Funkcije podobja v poeziji K. Koviča, D. Zajca in G. Strniše. Maribor: Slavistično društvo.

Ana PEPELNIK, 2007: Ena od variant, kako ravnati s skrivnostjo. Ljubljana: LUD Literatura.

- -, 2009: Utrip oranžnih luči na semaforju. Ljubljana: LUD Literatura. 
Radharani PERNARČIČ, 2008: Vesolje žalujko, veter žaluzije. Ljubljana: KUD France Prešeren Trnovo.

Eva PETRIČ, 2007: Ta prostor je škatla. Celovec: Drava.

Klemen PISK, 1998: Labas vakaras. Ljubljana: Mladinska knjiga.

- -, 2000: Visoko in nagubano prapočelo. Novo mesto: Goga.

- -, 2002: Mojster v spovednici. Grosuplje: Mondena.

Katja PLUT, 1997: Dober tek. Novo mesto: samozaložba.

- -, 2001: Ej! Novo mesto: Goga.

- -, 2005: Štafeta hvaležnosti. Maribor: Litera.

Gregor PODLOGAR, 1997: Naselitve. Ljubljana: Aleph.

- -, 2002: Vrtoglavica zanosa. Ljubljana: Center za slovensko književnost.

- -, 2006: Milijon sekund bliže. Ljubljana: LUD Literatura.

- -, 2010: Vesela nova ušesa. Ljubljana: LUD Šerpa.

Barbara POGAČNIK, 2007: Poplave. Ljubljana: MK.

- -, 2008: V množici izgubljeni papir. Ljubljana: LUD Literatura.

Andraž POLIČ, 1995: Hamlet v Karpatih. Ljubljana.

- -, 2000: Miniature. Slovenija: Produkcija Baterija.

- -, 2002: Brlog besed. Ljubljana: Sto prijateljev.

- -, 2003: Srečevanja. Ljubljana: Cankarjev založba.

- -, 2004: Zrcala na razpotju. Novo mesto: Goga.

- -, 2004: Arabeske. Ljubljana: Društvo Apokalipsa.

--, 2006: Bližine: ujeti glas. Ljubljana, Cankarjeva založba.

- -, 2008: Voda puščave. Ljubljana: KUD France Prešeren Trnovo.

- -, 2008: Na prvem tiru. Ljubljana: Forum.

- -, 2010: Hoja. Maribor: Litera.

Denis PONIŽ, 2001: Slovenska lirika 1950-2000. Ljubljana: Slovenska matica.

--, 2002: Stoletje slovenske lirike 1900-2000. Ljubljana: CZ.

Irena NOVAK POPOV, 1999/2000: Slovenska poezija v devetdesetih letih. Jezik in slovstvo 45/4, 115-120.

- -, 2003: Refleksija pesniškega jezika v sodobni slovenski poeziji. Ljubljana: Center za slovenščino kot drugi/tuji jezik pri Oddelku za slovenistiko Filozofske fakultete.

- -, 2003: Sprehodi po slovenski poeziji. Maribor: Litera.

- -, 2010: Mlada slovenska poezija zadnjega desetletja. Ljubljana: Znanstvena založba Filozofske fakultete. 179-185. 
--, 2011: Rastlinsko in živalsko podobje v poeziji Svetlane Makarovič. Jezik in slovstvo 46/1-2, 49-62.

--, 2013: Sodobna slovenska poezija v literarni vedi. Slavistična revija 1, 60-75.

- -, 2014: Pesnik in glasbenik: skica sodobnih stičišč. Jezik in slovstvo 49/1, 3-19.

Marcello POTOCCO, 2002: Lila. Grosuplje: Mondena.

- -, 2005: Pripovedi o ovcah, ljudeh in drugih živalih. Ljubljana: LUD Literatura.

- -, 2007: Popravki pesniške zbirke. Ljubljana: LUD Literatura.

Vid SAGADIN, 2010: Drevored. Ljubljana: LUD Šerpa.

Marko SAMEC, 2001: Filistejec. Maribor: Grafiti studio.

- -, 2005: Pljusk. Maribor: Litera.

Robi SIMONIŠEK, 2005: Potopljeni katalog. Ljubljana: LUD Literatura.

--, 2008: Avtoportret brez zemljevida. Ljubljana: LUD Literatura.

Jana PUTRLE SRDIĆ, 2003: Kutine. Ljubljana: Center za slovensko književnost.

- -, 2007: Lahko se zgodi karkoli. Ljubljana: Center za slovensko književnost.

Lucija STUPICA, 2000: Čelo na soncu. Ljubljana: Založba Beletrina.

- -, 2004: Vetrolov. Ljubljana: Založba Beletrina.

- -, 2008: Otok, mesto in drugi. Ljubljana: Založba Beletrina.

Jan ŠMARČAN, 2007: Njej. Maribor: Litera.

Aleš ŠTEGER, 1995: Šahovnice ur. Ljubljana: Mladinska knjiga.

- -, 1997: Kašmir. Ljubljana: Nova revija.

- -, 1999: Protuberance. Ljubljana: Študentska založba Beletrina.

- -, 2005: Knjiga reči. Ljubljana: Študentska založba Beletrina.

- -, 2010: Knjiga teles. Ljubljana: Študentska založba Beletrina.

Tomo VIRK, 2003: Moderne metode literarne vede in njihove filozofsko teoretske osnove. Ljubljana: Univerza v Ljubljani.

Maja VISINSKI, 2008: Zgladi me v žensko. Ljubljana: JSKD, Mentor.

Tomislav VREČAR, 1997: Punk še ni hin. Ljubljana: KUD France Prešeren.

- -, 1998: Vaš sin vsako jutro preganja mačke po soseski. Ljubljana: KUD France Prešeren.

--, 2003: Ko se mi vse ponuja, se meni kuja. Ljubljana: KUD France Prešeren.

--, 2004: Naj me koklja brcne. Ljubljana: LUD Šerpa.

- -, 2009: Kurc pesmi. Ljubljana: LUD Literatura.

Jure VUGA, 2009: Pod kamni plešem. Ljubljana: Založba Beletrina. 
Lučka ZORKO, 2001: Reciklaža kosti. Murska Sobota: Mladinski informativni in kulturni klub.

--, 2004: Obdukcija srca: knjiga o razmladičenju. Murska Sobota: ZKD.

--, 2006: Karavana. Murska Sobota: Zveza kulturnih društev.

_-, 2011: Vreščeče čeri. Maribor: Litera.

Uroš ZUPAN, 2003: Sutre. Ljubljana: LUD Šerpa.

Petra ZUPANČIČ, 2010: Premog. Ljubljana: LUD Literatura.

Barbara ŽVIRC, 2004: Oblakov, da iz njih iztisnem morje. Slovenj Gradec: Višja strokovna šola.

\section{FEATURES IN POETRY OF THE MAIN SLOVENIAN POETS BORN AFTER 1970}

Literary theorists, historians and publicists have described the generation of poets born after 1970 in terms of autopoetics and expressive individualism, but there are a number of additional features which characterize all levels of poetic texts. Using the research criteria described in this paper we observe sixty-one poetics used by the major Slovenian poets and describe the usage of these features at four distinct levels: external structure, external style, external rhythm and internal structure. At the level of external structure we analyze the content and morphological nature of titles, the scope of stanzas and verses and eventual art occurrences. Under external style we consider the most significant and frequent stylistic means while drawing attention to excessively hermetic poetic texts and excessive imitation of past poetic voices and concepts, both features which are often overused in poetic appeals to past voices and concepts. At the level of external rhythm we highlight three designs, drawing special attention to the rhythm of prose poems and to rhythmic modes which evoke classical metric models. Finally, under internal structure we consider the position of the lyrical subject and other dominant themes, including themes of the poet and poetry, the intellectual, language, the individual in relation to himself, duality and collective, and also the understanding of the truth through the idea of partiality and the worthlessness of its own confession. We conclude with a brief overview of the conceptual orientation which arises from an ahistorical analysis of these features. In so doing, we draw attention to the developmental continuum which takes place within this generation of Slovenian poetry, and remark on the inappropriateness of analyzing the poetics of an already-established poetic generation. 